\title{
Private Forestry in Transition
}

\author{
By Samuel T. Dana
}

$\mathrm{F}$ ROM colonial days to the present, the forests of the United States have played a major role in its development. They have built its homes, supplied the raw material for many of its manufactured products, provided containers for their shipment, and helped to prevent erosion and floods. These products and services have come, and must continue to come, mainly from the three-fourths of our forest area that is in private ownership. What are the prospects that this area of 345 million acres will be so managed as to guarantee adequate future supplies and services?

Until recently most students of the situation have viewed it with uneasy concern or even genuine alarm. For more than half a century they have emphasized the key position in the national economy occupied by forest lands in private ownership, and have successively proposed public co-operation, public regulation, public ownership, and private initiative as means of assuring their effective management.

\section{Public Co-operation and Regulation Proposed}

In 1899 in his first report as Chief of the Division of Forestry, Gifford Pinchot commented optimistically on the program which he had initiated to further the practice of forestry on private lands by public co-operation in the preparation of forest working plans. The response was encouraging; but the resulting plans so commonly gathered dust in a convenient pigeonhole that some ten years later a wag summed up progress with the remark that "forestry is now being practiced everywhere ex- cept in the woods." The co-operative approach was renewed in different form in the Weeks Act of 1911, the ClarkeMcNary Act of 1924, the Norris-Doxey Act of 1937, and the Cooperative Forest Management Act of 1950. Results have been more substantial, but have fallen far short of bringing private forest lands in general under even fairly satisfactory management.

In 1919 the Forest Service, under the leadership of Henry S. Graves, and the Society of American Foresters, under the leadership of Frederic E. Olmsted and Gifford Pinchot, started a campaign to solve the problem by public regulation of cutting on private lands. Mr. Pinchot summarized his views with characteristic vigor:

Forest devastation will not be stopped through persuasion, a method which has been thoroughly tried out for the past twenty years and has failed utterly. Since otherwise they will not do so, private owners of forest land must now be compelled to manage their properties in harmony with the public good. Pressure from without, in the form of public sentiment, crystallized in compulsory nation-wide legislation, is the only method that promises adequate results. To apply this method successfully means to fight.

Legislatively, the only immediate result of this campagin was the strengthening of the federal program in the fields of public co-operation and public ownership by the passage of the ClarkeMcNary Act. Today federal regulation, in spite of sporadic attempts by the Forest Service to obtain its adoption, seems more remote than ever. State regulation has made some progress, but is neither sufficiently wide- 
spread nor effective enough to offer any real promise of providing a panacea.

\section{Public Ownership Proposed}

In 1933 the Forest Service, in the Copeland Report ("A National Plan for American Forestry"), subordinated public co-operation and public regulation to public ownership as the most effective means of solving the forest problem. This report prepared under the supervision of $\mathbf{E}$. $\mathrm{H}$. Clapp during the incumbency of R. Y. Stuart as Chief of the Forest Service, expressed the view "that practically all of the major problems of American forestry center in, or have grown out of, private ownership." To meet the situation, it recommended the acquisition of 134 million acres of forest land by the Federal Government and of 90 million acres by state governments. This proposal, which would have more than trebled the area of commercial forest land at that time in public ownership, was made during the depth of the depression when some private owners, particularly in the West, were inclined to regard their forest lands as a liability rather than an asset, and to regret that the government had ever allowed them to assume the "burden" of ownership. It was endorsed by Secretary of Agriculture Henry A. Wallace, who strongly recommended the earliest possible action on the federal part of the plan.

Although the area of forest land in public ownership has increased substantially in the last twenty years, this increase has been meager indeed in comparison with the goal set by the Copeland Report. Today the Federal Government owns 19 per cent of the commercial forest area, and state and smaller units of government 6 per cent, with no apparent likelihood of any marked increase in either category. That we shall now attempt to solve the problems created by private owner- ship by largely abolishing such ownership seems most improbable.

\section{SelF-REgulation}

The year of the Copeland Report (1933) may also be regarded as the year of the first attempt to put private forestry on the map by mobilizing private initiative on a nation-wide scale. Article $\mathrm{X}$ of the Code of Fair Competition for the Lumber and Timber Products Industries provided that:

the applicant industries undertake, in cooperation with public and other agencies, to carry out such practicable measures as may be necessary for the declared purposes of this code in respect of conservation and sustained production of ${ }^{-}$forest resources.

Wilson Compton, general manager of the National Lumber Manufacturers Association, promptly announced that "this is an industry undertaking. It will be so administered."

Two large conferences of representatives of industry and of the general public led to agreement on the principles to be followed in the drafting for each forest region of the country of codes of forest practice which would have the force of law. This procedure, known as "self-regulation," was lauded as a desirable and effective alternative to public regulation.

Considerable progress in the preparation and adoption of regional rules of forest practice had been made by the spring of 1935, when the National Industrial Recovery Act was declared unconstitutional by the Supreme Court. Thereupon the interest of most forest owners and operators in the entire enterprise suddenly waned, although in some regions consideration was given to the desirability of going ahead with the program in spite of the invalidation of the act. This loss of interest may have been due to economic conditions (the depression was still with us), to lack of 
faith in the virtues of forestry as a voluntary undertaking, or to preoccupation with other matters. Whatever the cause, it strengthened the skepticism of those who believed that self-regulation would materialize only under the spur of legal compulsion; and it led F. A. Silcox, currently head of the Forest Service, to renew the campaign for public regulation.

One region where organized effort by industry to push private forestry did crystallize into definite action was the Pacific Northwest. Here the timber associations took seriously the excellent rules of forest practice which they had developed. Sustained timber production, in their judgment, was highly desirable from both the public and the private point of view, Article $\mathrm{X}$ or no Article X. Two developments of major consequence soon followed, both in 1941: (1) the passage by Oregon, with the support of the timber interests, of legislation requiring private owners to adopt minimum standards of forest practice; and (2) the inauguration of the tree-farm movement by the establishment of the Clemons Tree Farm in Washington by the Weyerhaeuser Timber Company.

The same year saw the organization of American Forest Products Industries, Inc. (AFPI)-the educational arm of the forest industries. Under its aegis the keep-green and the tree-farm programs have gone steadily forward, accompanied by a vigorous campaign for the education both of the general public and of forest owners. Regional associations and individual owners, and of course the federal and state governments, have also played an important part in the general advance.

\section{Status of Private Management}

Where, then, does private forestry stand today, and what are its prospects for the future? Is the perennial prob- lem of American forestry-management of private lands-actually on its way to a satisfactory solution? Is the outlook as rosy as the optimists in industry believe, or as dark as the pessimists in government fear?

The answer to these questions, in the judgment of a middle-of-the-roader like the present writer, is that private forestry is in a state of transition from a position of minor importance in the national economy to one of major importance. It has come a long way in recent years; it still has a long way to go; and liberal public participation in the forestry enterprise will continue to be necessary for satisfactory progress.

Private forestry has gone farther in the last decade than in all the previous

TABLE 1-TREE FARMS AS OF March 1, 1951

\begin{tabular}{l|r|r|r|r}
\hline \multicolumn{1}{c|}{ Region } & $\begin{array}{r}\text { Num- } \\
\text { ber }\end{array}$ & $\begin{array}{c}\text { Per } \\
\text { Cent }\end{array}$ & Acres & $\begin{array}{r}\text { Per } \\
\text { Cent }\end{array}$ \\
\hline West & 492 & 14 & $8,649,830$ & 35 \\
South & 1,899 & 53 & $14,204,200$ & 57 \\
Lake & 497 & 14 & $1,503,662$ & 6 \\
Central and Plains & 346 & 10 & 150,629 & 1 \\
Eastern & 307 & 9 & 354,917 & 1 \\
United States & 3,541 & 100 & $24,863,238$ & 100 \\
\hline
\end{tabular}

years of our history put together. The number of well-managed properties has jumped suddenly from the hundreds into the thousands. The rapidity of the change is dramatized by the growth in the number of tree farms from one in 1941 to more than thirty-five hundred today. Their number and distribution as of March 1, 1952, were as shown in Table 1.

According to AFPI, the sponsor of the tree farm movement,

A tree farm is an area of privately owned forest land devoted primarily to the continuous growth of merchantable forest products under good forest practices. . . . 
Tree farming, like the raising of any crop, is a practical business venture.

Both the idea and the name have proved so popular that thirty-three states now have formal tree-farm programs. Each of these states has a responsible agency to establish and enforce standards of practice, compliance with which entitles an owner, whether of a small farm woodlot or a large industrial holding, to be officially certified as a tree farmer.

In interpreting tree-farm figures such as those given above, two offsetting facts must be kept in mind. In the first place, many of the properties included in them were being well managed in pre-tree-farm days. Secondly, they do not include well-managed properties that have not yet been registered or that are in non-tree-farm states. Statistical accuracy, however, is not necessary to prove to the careful observer that there has been an unforeseen and highly gratifying upsurge in the practice of private forestry. This is most evident on the lands of pulp and paper companies, which have been leaders both in the area placed under management and in the quality of that management. Their interest is due to the phenomenal growth of the industry, which increased its production even during the depression; to its heavy capital investment, which makes an assured supply of raw material indispensable; and to technological advances, which have made possible the utilization of species and grades of material that were formerly unavailable.

\section{Activities OF THE INDUSTRY}

The new attitude is well stated on the letterhead of the country's largest private timberland owner: "Timber is a crop." It finds expression in the woods, both on tree farms and elsewhere, in more effective control of fire, insects, and disease; in thinnings, cleanings, and other silvicultural treatments in immature stands to improve the quality of the final crop; in the conduct of harvesting operations so as to obtain natural reproduction of desirable species in adequate amount; in the artificial reforestation of denuded areas; in the development of permanent systems of transportation; and in the practice of sustained-yield management, through which the balancing of growth and drain assures continued forest production for an indefinite future. It also finds expression in the general acquisition by larger owners (especially in the paper industry) of small holdings which for economic reasons cannot be handled satisfactorily by their present owners and are likely to be much better managed as integral parts of an extensive timber-growing enterprise.

In some instances private management is even more intensive than that on national forests, where standards have long been high. Moreover, the Southern Pulpwood Conservation Association and several individual owners assist smaller owners without charge in the management of their land. Such assistance may include the marking of the trees to be cut in a logging operation and the furnishing of planting stock for reforestation purposes. This is not entirely an altruistic gesture, but rather an intelligent approach to the problem of assuring an adequate supply of wood to meet the manufacturer's needs for raw material.

All these activities are normally conducted under the professional direction of a trained forester, who may be on the staff of the owner, employed by him on a consulting basis, or made temporarily available in an advisory capacity by a public agency. Some 5,100 foresters are now estimated to be employed by industry. Several of the larger companies have a score or more of foresters 
on their payrolls, many in positions of responsibility for the determination of policy as well as of technical practice. A few concerns go so far as to employ specialists for research in such fields as forest pathology, forest entomology, and forest soils. Experimental forests, sometimes aggregating many thousand acres, are not uncommon. One of the most encouraging features of the situation is that current openings for foresters in private employ considerably exceed those in public employ.

\section{PUblicity Work}

Prominent in the efforts being made in many quarters to put private forestry on the map is American Forest Products Industries, to which reference has already been made. This organization has been largely responsible for putting across the keep-green program in 31 states, the tree-farm program in 33 states, and the more-trees program in 6 states. It issues a large volume of attractive literature designed to get more forestry practiced on private lands; to inform the general public, and especially school children, as to the importance of forests, forest products, and forest industries in the life of the nation; and to make known what industry is doing to assure adequate future supplies. In 1951, for example, educational material was sent to 89,000 schools in all parts of the country.

Naturally, activity of this sort has led to the charge that industry is indulging in propaganda to lull the American people into a false feeling of security. Careful study of the literature issued both by AFPI and by individual companies fails to substantiate the charge. While the general presentation is usually optimistic, sometimes perhaps too optimistic, reference is nearly always made to the fact that the forest situation as a whole is not satisfactory, and that all of us must put our shoul- ders to the wheel to make it more so. If this constitutes advertising and window dressing, it must be remembered that advertising and window dressing are part and parcel of the entire system of private enterprise. From radio and newspaper to the department store's window display, they are characteristic of American business. And is it any wonder that timberland owners should emphasize the bright spots in the present picture after the names they have been called and the unfavorable publicity they have previously received?

\section{Motivation of Advance}

The important question is: How permanent and how effective is the recent upsurge in private forestry? In an economic world, it is encouraging that the primary cause of the new interest is an economic one. Owners have not suddenly "got religion" or become panicky because of fear of federal regulation; nor are they unduly influenced by the opportunity to invest in their own business funds that would otherwise go to the government as income taxes. They have decided to go into the business of growing timber because it pays. High stumpage prices, the closer utilization of inferior material made possible by advances in wood technology, and the necessity of protecting heavy investments in land and mills now justify practices which most owners, rightly or wrongly, formerly regarded as uneconomical. Added to the economic motive, on the part of some at least of the larger manufacturers, is a sense of responsibility for the maintenance of the communities supported by their plants.

Enlightened self-interest thus provides a solid foundation which offers real promise of permanence. Another depression would undoubtedly lead to some decrease in expenditures for forestry by private owners, just as it would lead to economies in other direc- 
tions. That it would result in the virtual abandonment of any considerable part of the present program is most unlikely, particularly in the case of manufacturers with heavy capital investments. The stakes are too high.

\section{Good But Not Good Enough}

On the other hand, accomplishments to date in relation to needs give no cause for complacency. Forest Service estimates showing the status of forest management in 1945 are given in Table 2. Additional areas have come under management since that date, and the

TABLE 2-Character of Cutting in 1945 (Per cent)

\begin{tabular}{l|c|c|c}
\hline \hline & $\begin{array}{c}\text { Good } \\
\text { and } \\
\text { Better }\end{array}$ & Fair & $\begin{array}{c}\text { Poor } \\
\text { and } \\
\text { Worse }\end{array}$ \\
\hline Private ownership & 8 & 28 & 64 \\
$\quad$ Small & 4 & 25 & 71 \\
$\quad$ Medium & 8 & 31 & 61 \\
Large & 29 & 39 & 32 \\
Public ownership & 67 & 19 & 14 \\
$\quad$ National forests & 80 & 19 & 1 \\
$\quad$ Other federal & 43 & 32 & 25 \\
$\quad$ State and local & 47 & 10 & 43 \\
All lands & 23 & 25 & 52 \\
\hline
\end{tabular}

intensity of management on other areas has no doubt increased. Even so, the level of management of the private forests is clearly low, both intrinsically and in comparison with that of the public forests. This is notably true of the small holdings (less than 5,000 acres) and the medium-sized holdings $(5,000$ to 50,000 acres), with only 4 and 8 per cent respectively under good or better management. The large owners, particularly the pulp and paper companies, are doing much better, with 29 per cent of the area involved under good or excellent management; but this group includes only 15 per cent of the total forest area in private ownership.
A closer look at the situation in one of the most productive forest areas in the country, the southern pine region, is revealing. Here the pulp and paper industry has increased its output nearly ten times in the last twenty years, with another marked expansion scheduled for the immediate future. Although pulp and paper manufacturers are almost uniformly practicing good forestry on their own lands, these are far from adequate to meet their requirements. They must therefore obtain about half of their wood supply, in competition with the lumber industry and other woodusing industries, from other lands. Of these, the most important are the small ownerships, which greatly predominate in the region, and only 2 per cent of which are being well handled. Clearly, the progress which has so far been made, spectacular as it is on some individual properties, is far from enough.

Forest Service estimates also show that the total growth of the forests (in cubic feet) approximately equals the total drain resulting from cutting and from losses by fire, insects, and disease, and that the growth of sawtimber (in board feet) is about two-thirds of the drain. Do these figures mean that more widespread and more intensive forest management, whether on public or private lands, is not really an urgent necessity? They mean no such thing, unless we are to be satisfied with a static supply of wood in an expanding economy; and unless we are willing to reduce drastically our consumption of saw timber, on which we now depend for many important uses.

Wood, in spite of the much-advertised increase in the use of substitutes, continues to be the "universal raw material." Far from being "obsolete," it is constantly finding new uses and being improved for old uses. From lumber, plywood, and the myriad articles manufactured from them, to turpentine and 
rosin, paper and its products, lignin, sugar, alcohol, vanillin, and other chemical derivatives, forest products enter into our daily life not only in many obvious but also in many unrecognized ways. Our whole economy will be richer or poorer as they are abundant or scarce.

Liberal use of forest products is desirable because of their renewability as well as because of their utility. It is reassuring to know that about a fourth of our total land area is best suited to the production of forest crops, and that these 461 million acres, if properly managed, would permanently provide a much larger yield than we are now harvesting.

\section{The Social Requirement}

Is any such addition to the national wealth in the form of increased forest production likely to result from private enterprise alone? In spite of the recent highly encouraging developments in private forestry, the answer is almost certainly No. - The job is of a nature and a size to require public participation. There is nothing inconsistent with the "American way of life" in this conclusion.

The institutions of private property and private profit are based on the theory that they best serve the interests of society as a.whole. Here in the United States we are convinced that this is the case; but when unrestricted freedom of enterprise fails to render optimum service or results in actual disservice, the community does not hesitate to intervene. Public schools, agricultural experiment stations, blue-sky laws, pure food and drug acts, regulation of public utility rates and service, incentive payments, zoning ordinances, control of stream pollution, and national parks, to pick just a few examples, all bear witness to this fact.

Experience both here and abroad shows that forestry is a field in which such intervention is often desirable. Many owners are either unable or unwilling to handle their lands in such a way as to assure their continued productivity. When forest supplies are abundant in relation to the demand, this fact may have little social significance. When the situation becomes reversed, it may be of outstanding importance. Indeed, as population expands and natural resources shrink, the point may well be reached where the way in which they are managed is of more concern to the community at large than to their individual owners.

The United States cannot raise the standard of living for its own rapidly mounting population, nor can it exercise effective leadership in a bankrupt world, without wise use of its natural resources, among which forests are of major importance. The goal must be reached chiefly through action of private owners, but with a reasonable measure of the three forms of public participation with which we are already familiar.

\section{Forms of Public Participation}

Public co-operation is exemplified in such fields as protection of forests from fire, insects, and disease; research; education; provision of planting stock; and on-the-ground aid in the management of specific properties. These activities are almost universally approved, including the liberal use of federal grantsin-aid administered by state agencies. They have demonstrated the ability of private owners and of federal and state officials to work together in the formulation and execution of constructive programs in which the participation of all concerned is on a wholly voluntary basis.

Public regulation commands less favor, even at the state level; but it is likely to prove necessary, particularly in connection with "protection forests," 
unless forest owners as a whole prove more amenable to educational influences here than they have proved in even such forest-minded countries as Norway and Sweden. It is significant that in Oregon and Washington, which now have the most drastic laws of any of the states, the legislation had the backing of the very owners who were to be regulated; and that in Washington these owners helped to get a decision from the state Supreme Court upholding the constitutionality of the act. In the words of L. F. Watts, chief of the Forest Service, regulatory measures constitute the "rules of the game" and "are as necessary in resource management as they are to transportation, communication, and other enterprises that affect the public welfare." Although mandatory in form, the fact that they automatically force an owner to consider the basic problem of sustained forest production gives them great potential educational value, which is magnified if private owners themselves participate in the regulatory process.

Public ownership to the extent of 25 per cent of the commercial forest area has resulted from the reservation of lands originally in federal or state ownership (chiefly the public domain), from the acquisition of additional lands by purchase or exchange, and by the retention of tax-delinquent lands. They include largely lands that are (or have been) submarginal for private ownership, and that are needed for purposes such as watershed protection and recreation, which are generally recognized as a public responsibility. The character of their management is less subject to the ups and downs of the business cycle than is the management of private lands, and they can be used for the production of timber of larger size and higher quality than most private owners can afford to grow. This latter function will continue to be an impor- tant one until the highly uncertain arrival of the day when technology makes it possible to substitute built-up and synthetic products for high-grade lumber and plywood with equal satisfaction from the standpoint of cost, utility, and beauty. That the present pattern of ownership is the best that could be devised is unlikely; but that a considerable backlog of public forests is highly desirable as a means of promoting stability and of providing intangible but essential services can hardly be doubted.

\section{Summary}

To sum up, private forestry is in a state of transition. Timber mining is at last being replaced by timber cropping on a substantial scale. Great credit is due to the individuals, companies, and organizations whose leadership has been responsible for the change. The evidence is convincing that the new attitude is here to stay, and that the movement which they have started will continue to spread.

Enthusiasm over recent progress should not, however, blind us to the fact that it is only a good beginning. Evolution, not revolution, is the order of the day. Neither the area of private forest land now under management nor the average quality of that management gives any assurance of a continuing supply of forest products adequate to meet the needs of a nation with a rapidly expanding population, a desire for ever higher standards of living, and a responsibility for world leadership. Current efforts by private owners must be intensified, extended, and supplemented (not supplanted) by appropriate activities on the part of public agencies.

Private forestry in the United States has come far in the last ten years. It has still farther to go. With full cooperation on the part of all concerned, there is reasonable hope of success in attaining the common objective of en- 
abling our forest resources to play the part they can and should in promoting and maintaining the prosperity of the nation. Industry's present attitude arouses hope and confidence that the transition from negligible planned pro- duction, through substantial production, to full production on the 75 per cent of our forest area in private hands will be faster than we had dared to hope. The prospect is one to encourage optimism but not complacency.

Samuel T. Dana, Sc.D., Ann Arbor, Michigan, is Filibert Roth University Professor of Forestry at the University of Michigan. He previously served in various capacities with the United States Forest Service for some twenty years, and has represented the United States Department of Agriculture, the Society of American Foresters, and Yale University at international conferences. He is author of many bulletins and reports in his feld, and is a contributor to the Journal of Forestry, of which he was editor in chief for six years. 